\title{
ESTIMATION OF AVERAGE ANNUAL COMMITTED EFFECTIVE DOSE DUE TO INGESTION FOR SOME MEDICINAL AND HERBAL PLANTS USED IN ALBANIA
}

\author{
Erjon Spahiu $^{1 *}$, Manjola Shyti ${ }^{2}$, Irma Bërdufi ${ }^{2}$

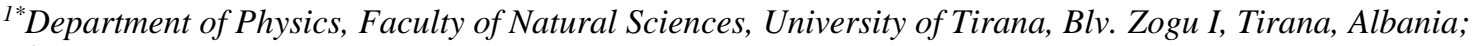 \\ ${ }^{2}$ Institute of Applied Nuclear Physics, University of Tirana, Str. Qesarake, P.O.Box 85,Tirana, Albania; \\ *Corresponding Author Erjon Spahiu, e-mail: erjon.spahiu@fshn.edu.al;
}

Received May 2020; Accepted June 2020; Published July 2020;

DOI: https://doi.org/10.31407/ijees10.302

\begin{abstract}
Albania is one of the most important European countries known for export and using of medicinal and herbal plants. The aim of this work has been to provide the data of Average Annual Committed Effective Dose (AACED) due to the ingestion of radionuclides from medicinal and herbal plants. Twenty samples were analyzed for activity concentrations of natural and artificial radionuclides using HPGe gamma spectrometry. The activity concentrations of natural radionuclides vary from 5.28 to $52.55 \mathrm{~Bq} \mathrm{~kg}^{-1}$ for ${ }^{226} \mathrm{Ra}, 4.22$ to $8.16 \mathrm{~Bq} \mathrm{~kg}^{-1}$ for ${ }^{232} \mathrm{Th}, 133.54$ to 839.96 $\mathrm{Bq} \mathrm{kg}{ }^{-1}$ for ${ }^{40} \mathrm{~K}$. The activity concentration of the artificial radionuclide of ${ }^{137} \mathrm{Cs}$ is found to vary between 0.40 and $15.94 \mathrm{~Bq} \mathrm{~kg}^{-1}$. The lowest and highest AACED values were found to be $0.0048 \mathrm{mSv} \mathrm{y}^{-1}$ and $0.034 \mathrm{mSv} \mathrm{y}^{-1}$ in the Blackthorn and Sage samples respectively. The highest value in this plant were about ten times smaller than the world average annual committed effective dose of $0.3 \mathrm{mSv} \mathrm{y}^{-1}$ provided in UNSCEAR 2000 report. Therefore, the radiological hazard due to ingestion of the natural and artificial radionuclides in these plants is insignificant. Thus, there is no radiological health risk in using of these medicinal and herbal plants.
\end{abstract}

Keywords: AACED, Gamma Spectrometry, Natural and Artificial Radionuclides, Medicinal and Herbal plants 